\title{
Sepsis in a university hospital: a prospective study for the cost analysis of patients' hospitalization
}

\author{
Sepse em um hospital universitário: estudo prospectivo para \\ análise de custo da hospitalização de pacientes \\ Sepsis en un hospital universitario: estudio prospectivo para \\ análisis de costo de la hospitalización de pacientes
}

Maynara Fernanda Carvalho Barreto ${ }^{1}$, Mara Solange Gomes Dellaroza ${ }^{1}$, Gilselena Kerbauy ${ }^{1}$, Cintia Magalhães Carvalho Grion ${ }^{1}$

How to cite this article:

Barreto MFC, Dellaroza MSG, Kerbauy G, Grion CMC. Sepsis in a university hospital: a prospective study for the cost analysis of patients' hospitalization. Rev Esc Enferm USP. 2016;50(2):299-305. DOI: http://dx.doi.org/10.1590/S0080-623420160000200017

${ }^{1}$ Universidade Estadual de Londrina, Londrina, PR, Brazil.

\begin{abstract}
Objective: To estimate the cost of hospitalization of patients with severe sepsis or septic shock admitted or diagnosed in the Urgent and Emergency sector at a university hospital and followed until the clinical outcome. Method: An epidemiological, prospective, observational study conducted in a public hospital in southern Brazil for the period of one year (August 2013 to August 2014). Sepsis notification forms, medical records and data of the cost sector were used for the collection of clinical and epidemiological data. Results: The sample comprised 95 patients, resulting in a total high cost of hospitalization $(\mathrm{R} \$ 3,692,421.00)$, and an average of $\mathrm{R} \$ 38,867.60$ per patient. Over half of the total value of the treatment of sepsis ( $\mathrm{R} \$ 2,215,773.50)$ was assigned to patients who progressed to death (59.0\%). The higher costs were related to discharge, diagnosis of severe sepsis, the pulmonary focus of infection and the age group of up to 59 years. Conclusion: The high cost of the treatment of sepsis justifies investments in training actions and institution of protocols that can direct preventive actions, and optimize diagnosis and treatment in infected and septic patients.
\end{abstract}

\section{DESCRIPTORS}

Sepsis; Cross Infection; Costs and Cost Analysis; Hospital Costs. 


\section{INTRODUCTION}

Sepsis is defined as a Systemic Inflammatory Response Syndrome (SIRS) triggered by a suspected or confirmed infection that can develop into severe sepsis when associated with organ dysfunction or septic shock ${ }^{(1-2)}$. This disease is a public health problem and a challenge for healthcare organizations because it is among the leading death causes in hospitalized patients ${ }^{(3)}$.

Despite technological and therapeutic advances, sepsis affects people of all age groups and genders, and is related to the high prevalence of mortality $(30-60 \%)^{(4)}$. According to the Instituto Latino Americano da Sepse, the syndrome is the leading cause of death in Intensive Care Units (ICU) and a major cause of delayed hospital mortality, beating myocardial infarction and cancer ${ }^{(5)}$.

Given the high lethality, severe sepsis and septic shock are one of the main cost-generating conditions in public and private sectors related to hospitalizations and treatment, and organ complications and dysfunction. This is explained by the demands of this condition, such as replacement therapy for organ dysfunction, high-cost drugs and thorough patient follow-up by the health team ${ }^{(6)}$.

According to the report of the Surviving Sepsis Campaign, in 2003 were reported 398,000 cases and 227,000 deaths from septic shock in Brazi ${ }^{(5)}$. Approximately $\mathrm{R} \$ 17.3$ billion are used annually in the treatment of septic patients, of which $\mathrm{R} \$ 10$ billion are targeted to patients progressing to death, generating economic impact ${ }^{(5,7)}$.

The high mortality of septic shock and severe sepsis, and high costs associated with their treatment show the need for prevention and early diagnosis ${ }^{(8)}$. Therefore, knowing the costs generated by sepsis in health services can help to estimate the economic and social burden, and reinforces the importance of preventive measures. Given the above, the aim of this study was to estimate the cost of hospitalization of patients with severe sepsis or septic shock admitted or diagnosed in the Urgent and Emergency sector of a university hospital who were followed until the clinical outcome.

\section{METHOD}

This is an epidemiological, prospective, observational study involving all adult patients admitted or diagnosed with severe sepsis or septic shock in the Urgent and Emergency sector of the university hospital in southern Brazil between August 2013 and August 2014.

The inclusion criteria were all patients aged over 14 years, diagnosed with severe sepsis or septic shock according to the current sepsis criteria (International Sepsis Definitions Conference) $)^{(9)}$ during assistance in the Urgent and Emergency sector. Cases of death within the first 24 hours of care were excluded.

The analysis variables were the following: gender, age of patient, focus of infection (Centers for Disease Control and Prevention/National Healthcare Safety Network) $)^{(10)}$, hospitalization period, health care cost, and clinical outcome (discharge or death). The patient follow-up starting from their admission to institution until the clinical outcome allowed the mapping of hospitalization in different sectors: Urgent and Emergency, Intensive Care Unit (ICU) and medical-surgical inpatient units. Note that patients did not remain in the Urgent and Emergency sector throughout the whole period of hospital stay, but were referred to other hospital departments such as female or male inpatient units and Intensive Care Units.

Data collection was performed through sepsis notification forms of the management sepsis protocol of the institution recommended by the Instituto Latino Americano de Sepse ${ }^{(5)}$, medical records, and data from the cost sector. The notification forms had patient identification, gender, age, focus of infection, severe and shock sepsis classification criteria, date and time of organ dysfunction diagnosis.

The cost sector has provided the average daily costs corresponding to the months of the study referring to the hospitalization days in the respective sectors. The direct costs were considered to calculate the average hospitalization cost of patients per unit, namely: personnel and taxes, outsourced services, materials and medicines. The indirect costs consisting of apportionment costs of support services were also considered, such as laundry, maintenance, etc., as well as apportionment costs of the examination structure and/or clinical, medical and hospital procedures.

Next, the patients' hospitalization costs were estimated by using hospitalization stay (days) versus the average daily cost per admission unit corresponding to the period of hospital stay. The estimated cost is considered as the sum of hospitalization days multiplied by the daily value/inpatient unit. The calculation of costs in US dollars (US\$) considered the value of US\$1 = R\$2.239, according to the exchange rate quoted in August 2014.

The Statistical Package for the Social Sciences (SPSS) version 20 was used for tabulation and data analysis. Categorical variables were analyzed in the form of simple frequency, medians and quartiles, shown in tables and figures. The comparison between variables was performed by Pearson's and Mann-Whitney tests, and the significant difference was established at $\mathrm{p} \leq 0.05$. The dispersion of data was performed according to hospitalization days and hospital costs. The cost results were presented as median and interquartile range. Threshold values (called outliers) were presented to demonstrate the variation of hospitalization period, which can be affected by several factors. This study was approved by the Ethics Committee on Research involving Human Beings (Process number 884 268) and the Certificate of Presentation for Ethical Consideration (CAAE - Certificado de Apresentação para Apreciação Ética) number 0015.0.268.000-11 is available for public consultation.

\section{RESULTS}

Of the 95 patients, 56 (58.9\%) were identified with severe sepsis and 39 (41.1\%) with septic shock. Of all patients admitted to the studied institution, $43.3 \%$ had some organ dysfunction related to sepsis, and the others have developed sepsis during hospitalization in the Urgent and Emergency 
sector. As for epidemiological variables, female gender was more frequent (52.6\%), and the age range was 18-98 years, mean of 64.19 years (SD-24.4). The median length of hospital stay was 17 days, ranging between 1-147 days, 24 days on average (SD-24.4).

Regarding the focus of infection, some patients had more than an infection related to sepsis, totaling 102 infections. The patient infection rate showed a predominance of pulmonary focus $(n=73 ; 76.8 \%)$ corresponding to pneumonia, urinary tract infection $(n=10 ; 8.4 \%)$, both infections ( $\mathrm{n}=8 ; 8.4 \%)$, abdominal infection $(\mathrm{n}=3 ; 3.2 \%)$ abdominal focus, and associated abdominal and osteoarticular infections $(n=1,1 \%)$.

As illustrated in Figure 1, in relation to the classification of sepsis and clinical outcome among patients with severe sepsis criteria (56), just over half were discharged (51.8\%), and among patients with septic shock (39), the majority died (74.4\%). We observed that septic shock was associated with higher incidence of death $(74.3 \%$; $=0.017)$.

The average cost of hospitalization of septic patients was $\mathrm{R} \$ 38,867.60$ (US\$17,359.30) and the sum of the cost of all patients was R\$3,692,421.00 (US\$1,649,138.40). The data for hospitalization calculations made available by the cost sector are shown in Table 1 . The distribution of expenditures according to the clinical outcome, sepsis classification, patient's age and associated factors are shown in Table 2.

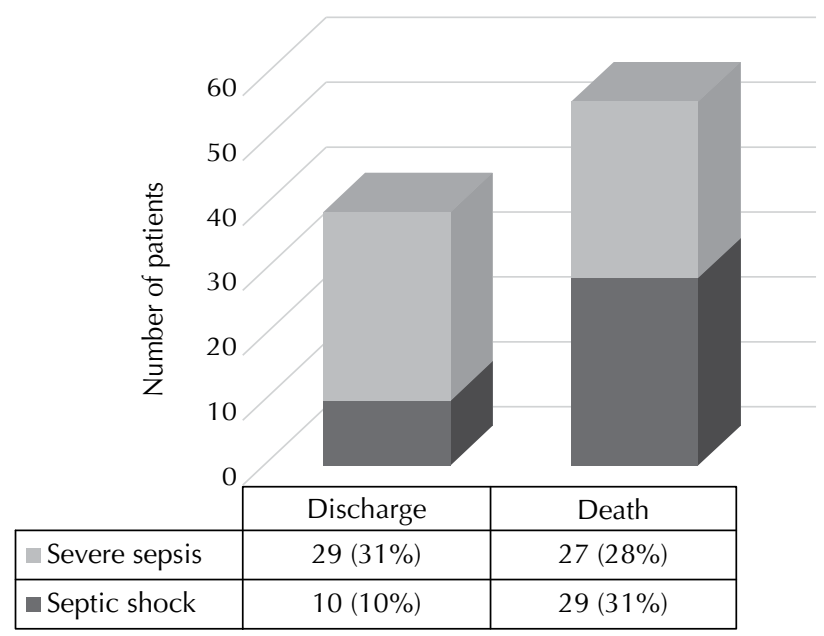

Figure 1 - Distribution of severe sepsis and septic shock diagnosis according to the patients' outcome - Londrina, Paraná, Brazil, 2015.

Table 1 - Statement of average daily costs (in real and American dollar) of the hospital units where patients were hospitalized. Londrina, PR, Brazil, 2015.

\begin{tabular}{|c|c|c|c|c|c|c|c|c|c|c|c|c|c|}
\hline $\begin{array}{l}\text { SECTORS } \\
\text { Patient/day }\end{array}$ & $\begin{array}{c}\text { August } \\
2013\end{array}$ & $\begin{array}{c}\text { September } \\
2013\end{array}$ & $\begin{array}{c}\text { October } \\
2013\end{array}$ & $\begin{array}{c}\text { November } \\
2013\end{array}$ & $\begin{array}{c}\text { December } \\
2013\end{array}$ & $\begin{array}{c}\text { January } \\
2014\end{array}$ & $\begin{array}{c}\text { February } \\
2014\end{array}$ & $\begin{array}{c}\text { March } \\
2014\end{array}$ & $\begin{array}{l}\text { April } \\
2014\end{array}$ & $\begin{array}{l}\text { May } \\
2014\end{array}$ & $\begin{array}{l}\text { June } \\
2014\end{array}$ & $\begin{array}{l}\text { July } \\
2014\end{array}$ & $\begin{array}{c}\text { August } \\
2014\end{array}$ \\
\hline \multicolumn{14}{|l|}{ ICU - 1} \\
\hline Real & $3,029.70$ & $3,121.01$ & $2,917.84$ & $3,022.38$ & $3,007.83$ & $3,605.30$ & $2,915.90$ & $2,981.49$ & $2,993.37$ & $5,545.05$ & $3,967.24$ & $3,349.09$ & $3,177.08$ \\
\hline Dollar & $1,353.15$ & $1,393.93$ & $1,303.19$ & $1,349.88$ & $1,343.38$ & $1,610.23$ & $1,302.32$ & $1,331.62$ & $1,336.92$ & $2,476.57$ & $1,771.88$ & $1,495.80$ & $1,418.97$ \\
\hline \multicolumn{14}{|l|}{ ICU - 2} \\
\hline Real & $3,654.04$ & $4,036.91$ & $3,618.80$ & $4,161.54$ & $3,802.84$ & $4,442.61$ & $3,845.08$ & $3,740.63$ & $3,784.13$ & $4,254.07$ & $4,227.36$ & $4,159.35$ & $4,184.31$ \\
\hline Dollar & $1,632.00$ & $1,803.00$ & $1,616.26$ & $1,858.66$ & $1,698.45$ & $1,984.19$ & $1,717.32$ & $1,670.67$ & $1,690.10$ & $1,899.99$ & $1,888.06$ & $1,857.68$ & $1,868.83$ \\
\hline \multicolumn{14}{|l|}{ Male unit* } \\
\hline Real & $1,170.08$ & $1,008.23$ & $1,199.91$ & $1,158.08$ & $1,284.05$ & $1,083.32$ & $1,198.33$ & $1,282.68$ & $1,204.25$ & $1,222.90$ & $1,350.32$ & $1,566.82$ & $1,473.20$ \\
\hline Dollar & 522.59 & 450.30 & 535.91 & 517.23 & 573.49 & 483.84 & 535.21 & 572.88 & 537.85 & 546.18 & 603.9 & 699.79 & 657.97 \\
\hline \multicolumn{14}{|c|}{ Female unit** } \\
\hline Real & $1,015.50$ & $1,189.56$ & $1,313.67$ & $1,070.52$ & $1,290.90$ & $1,221.96$ & $1,186.43$ & $1,239.57$ & $1,247.12$ & $1,179.46$ & $1,264.52$ & $1,196.66$ & $1,168.47$ \\
\hline Dollar & 453.55 & 531.29 & 586.72 & 478.12 & 576.55 & 545.76 & 529.89 & 553.63 & 557.00 & 526.78 & 564.77 & 534.46 & 521.87 \\
\hline \multicolumn{14}{|c|}{ Communicable diseases } \\
\hline Real & $1,313.43$ & $1,248.31$ & $1,038.32$ & $1,257.16$ & $1,931.73$ & $1,179.37$ & $1,260.90$ & $1,141.36$ & 944.57 & $1,467.44$ & $1,156.88$ & $1,275.19$ & $1,321.32$ \\
\hline Dollar & 586.61 & 557.53 & 463.74 & 561.48 & 862.76 & 526.74 & 563.15 & 509.76 & 421.87 & 655.40 & 516.69 & 569.54 & 590.14 \\
\hline \multicolumn{14}{|c|}{ Urgent and Emergency } \\
\hline Real & 917.79 & $1,095.90$ & $1,106.95$ & 960.98 & $1,114.92$ & $1,026.27$ & $1,031.11$ & 970.91 & 924.63 & 874.58 & $1,115.43$ & $1,200.72$ & $1,164.57$ \\
\hline Dollar & 409.91 & 489.46 & 493.99 & 429.20 & 497.95 & 458.36 & 460.52 & 433.64 & 412.97 & 390.61 & 498.18 & 536.28 & 520.13 \\
\hline
\end{tabular}

*Male inpatient unit. **Female inpatient unit 
Table 2 - Hospital costs related to clinical outcome and diagnosis of sepsis, focus of infection and patients' age - Londrina, Paraná, Brazil, 2015.

\begin{tabular}{|c|c|c|c|c|c|c|c|}
\hline & \multicolumn{2}{|c|}{ Total Cost } & \multicolumn{2}{|c|}{ Median } & \multicolumn{2}{|c|}{ Interquartiles $\left(1^{\text {st }}\right.$ and $\left.3^{\text {rd }}\right)$} & \multirow{2}{*}{ Mann-Whitney test } \\
\hline & Real & Dollar & Real & Dollar & Real & Dollar & \\
\hline \multicolumn{8}{|l|}{ Outcome } \\
\hline Hospital discharge & $1,476,647.53$ & $659,512.07$ & $22,945.00$ & $1,0247.88$ & $1^{\text {st }} 9,993.00$ & $4,463.15$ & \multirow{3}{*}{$0.431(p=0.001)$} \\
\hline \multirow[t]{2}{*}{ Death } & \multirow[t]{2}{*}{$2,215,773.47$} & \multirow[t]{2}{*}{$989,626.38$} & \multirow[t]{2}{*}{$18,833.50$} & \multirow[t]{2}{*}{$8,411.57$} & $\begin{array}{c}3^{\text {rd }} 49,836.00 \\
1^{\text {st }} 6,932.50\end{array}$ & $\begin{array}{c}22,258.15 \\
3,096.25\end{array}$ & \\
\hline & & & & & $3^{\text {rd }} 51,861.00$ & $23,162.57$ & \\
\hline \multicolumn{8}{|l|}{ Classification of sepsis } \\
\hline Severe sepsis & $2,348,402.90$ & $1,048,862.39$ & $24,837.50$ & $11,093.12$ & $1^{\text {st }} 10,588.00$ & $4,728.90$ & \multirow{3}{*}{$0.518(p=0.001)$} \\
\hline \multirow[t]{2}{*}{ Septic shock } & \multirow[t]{2}{*}{$1,344,018.10$} & \multirow[t]{2}{*}{$600,276.06$} & \multirow[t]{2}{*}{$17,221.00$} & \multirow[t]{2}{*}{$7,691.38$} & $\begin{array}{c}3^{\text {rd }} 53,346.00 \\
1^{\text {st }} 8,234.00\end{array}$ & $\begin{array}{c}23,825.81 \\
3,677.53\end{array}$ & \\
\hline & & & & & $3^{\text {rd }} 49,836.00$ & $22,258.15$ & \\
\hline \multicolumn{8}{|l|}{ Focus of infection* } \\
\hline Pulmonary & $2,908,378.00$ & $1,298,962.93$ & $20,389.00$ & $9,106.30$ & $1^{\text {st }} 8,742.00$ & $3,904.42$ & \multirow{3}{*}{$0.345(p=0.001)$} \\
\hline \multirow[t]{2}{*}{ Urinary tract } & \multirow[t]{2}{*}{$723,328.00$} & \multirow[t]{2}{*}{$323,058.51$} & \multirow[t]{2}{*}{$17,221.00$} & \multirow[t]{2}{*}{$7,691.38$} & $\begin{array}{c}3^{\text {rd }} 40,825.50 \\
1^{\text {st }} 5,095.00\end{array}$ & $\begin{array}{c}18,233.81 \\
2,275.57\end{array}$ & \\
\hline & & & & & $3^{\text {rd }} 55,800.00$ & $24,921.84$ & \\
\hline \multicolumn{8}{|l|}{ Age group } \\
\hline Up to 59 years $(\mathrm{n}=32)$ & $1,295,281.00$ & $578,508.71$ & $29,679.00$ & $13,255.47$ & $1^{\text {st }} 8,495.50$ & $3,794.33$ & \multirow{3}{*}{$0.556(p=0.001)$} \\
\hline \multirow[t]{2}{*}{60 years or older $(n=63)$} & \multirow[t]{2}{*}{$2,397,140.00$} & \multirow[t]{2}{*}{$1,070,629.74$} & \multirow[t]{2}{*}{$19,220.00$} & \multirow[t]{2}{*}{$8,584.19$} & $\begin{array}{c}3^{\text {rd }} 63,248.25 \\
1^{\text {st }} 8,738.00\end{array}$ & $\begin{array}{c}28,248.44 \\
3,902.63\end{array}$ & \\
\hline & & & & & $3^{\text {rd }} 33,218.00$ & $14,836.09$ & \\
\hline
\end{tabular}

* Patients with exclusive pulmonary or urinary focus of infection were included in this calculation.

The results showed that the higher costs are related to between costs and hospitalization days $(r=0.826 ; p=0.01)$, the clinical outcome of discharge, diagnosis of severe sep- i.e., the length of hospitalization interferes with costs. sis, pulmonary focus of infection, and the age group of up Thus, the longer the hospital stay, the higher the hospital to 59 years (Table 1). There was also a positive correlation costs (Figure 2).

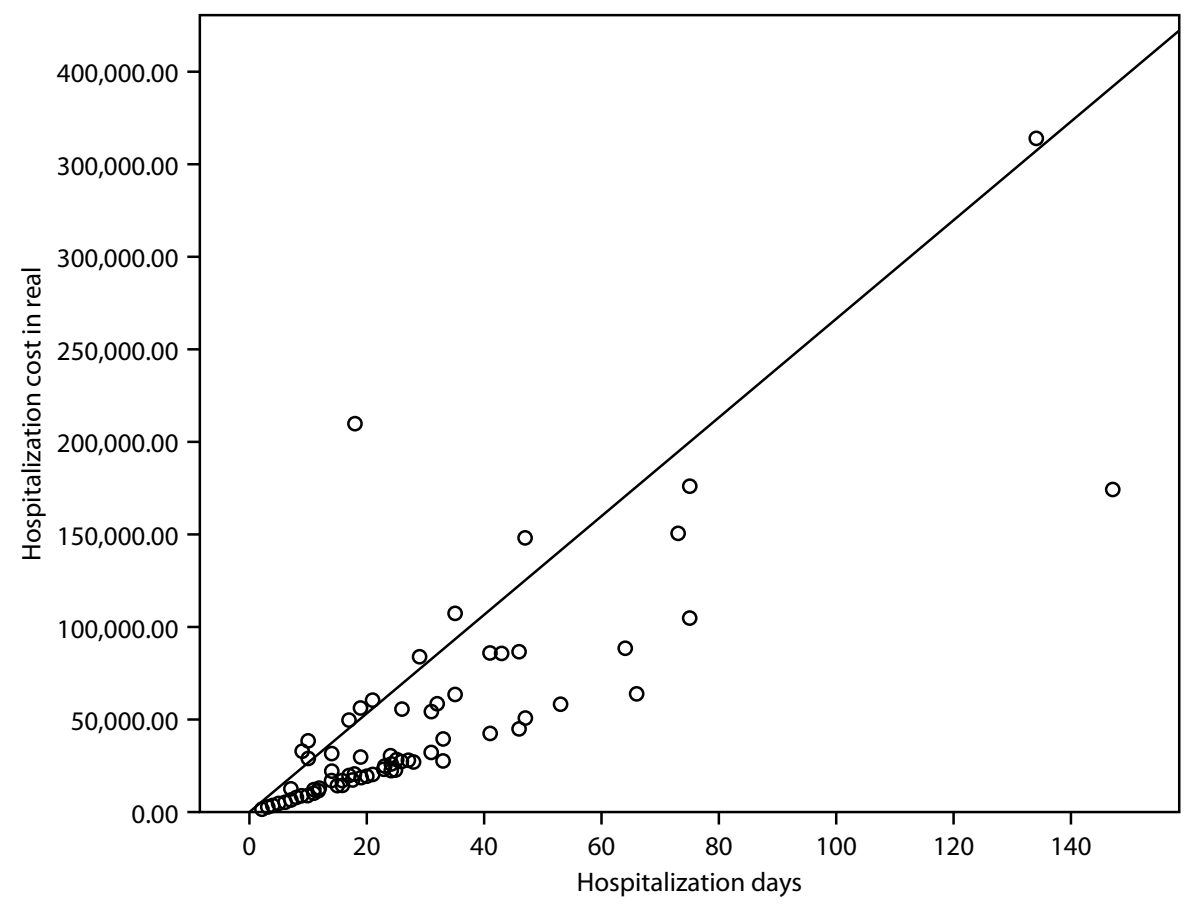

Figure 2 - Dispersal of the data according to hospitalization days and hospital costs in real currency. Londrina, Paraná, Brazil, 2015. 
For statistical analysis, we decided to keep the extreme values of two patients hospitalized for 134 and 147 days, respectively. They express the reality of health services, in which prolonged hospitalization significantly increases the therapeutic costs of certain health problems and the hospitalization costs of R $\$ 364,355.6$ (US\$ $162,731.5$ ) and R\$174,076.9 (US\$77,747.6) considered with the outliers.

\section{DISCUSSION}

Sepsis is a major health problem given its high mortality and morbidity. Regarding the management of financial resources of health services, this medical condition results in high costs and resources spent.

The study results are in agreement with this scenario, showing the high total cost $(\mathrm{R} \$ 3,692,421.00$; US $\$ 1,649,138.00)$ in the treatment of patients admitted or diagnosed with severe sepsis or septic shock in the Urgent and Emergency sector of the institution during a one-year period. In this perspective, a multicenter observational cohort study was performed in Brazil in 2008 with septic patients admitted to 21 ICUs of public and private hospitals. During a year, participants were followed from diagnosis of sepsis until the clinical outcome and the direct hospitalization costs were estimated. The results showed an average total cost per patient of US\$9,632.00 (R\$21,566.00) $)^{(11)}$.

This value is below that calculated in the current study, which was $\mathrm{R} \$ 38,867.6$ (US\$17,359.30) per septic patient, on average. The divergence is explained by the different scenarios of both studies because the multicenter study involved only ICUs, while the present study followed septic patients from admission until different hospital units.

Illustrating the European reality, a study performed in Ireland in 2014 found a relation between sepsis and factors that predict high hospital costs for patients admitted to the emergency room of secondary level hospitals, with an average of $€ 3,668.30$ ( $R \$ 6,045.50$ and US\$2,770.09) ${ }^{(12)}$. In France, the study identified 1698 patients with previous sepsis in the hospital admission unit and ICU, showing the average cost of severe sepsis of US $\$ 22,800.00$ $(\mathrm{R} \$ 51,049.20)^{(13)}$. This cost is close to that found in the present study, considering the similar methodology of following patients since hospital admission.

A study performed in the United States also found higher costs than the results of the present study. In the American study, the individual cost calculated for adult patients was around US\$21,000-25,000 (R \$ 47,019.00$55,975.00)$. For patients aged 1-19 years, the cost was US\$28,000.00 ( $R \$ 62,692.00$ ). The study also estimated that sepsis can affect adults and the elderly more than children $(0.2 / 1,000$ cases in children and 26.2/1,000 cases in $>85$ years old $)^{(7)}$.

The mean age of patients was 64.19 years, corroborating authors who showed prevalence of organ dysfunction associated with sepsis in patients aged over 58 years ${ }^{(11,14-15)}$.

Pneumonia and urinary tract infection were the main infectious focus of sepsis, and the pulmonary focus showed greater impact on costs $(\mathrm{R} \$ 2,908,378.00$, US\$ 1,298.962.93), compared with the urinary focus
( R\$ 723,328.00, US\$323,058.51). Both pneumonia ${ }^{(16)}$ and urinary tract infection ${ }^{(12)}$ are infectious foci commonly related to the evolution to sepsis. A prospective cohort study involving 14,364 patients hospitalized in international ICUs showed that among admitted septic patients, the predominant infectious foci were related to the respiratory, digestive and urinary tract. About $28 \%$ of total infections were associated with sepsis, $24 \%$ with severe sepsis, and 30\% with septic shock ${ }^{(17)}$.

As for hospitalization period, a study in Saudi Arabia with adult patients admitted between April 2007 and March 2010 in the medical-surgical ICU of a tertiary care hospital showed that patients with severe sepsis commonly had a prolonged stay in ICU and the hospital because of multiple organ failure and other disabilities related to sepsis $^{(3)}$. The average of the present study was close to 30 days of hospitalization, indicating that even in a relatively short period the expenses with sepsis treatment are high. This is possibly related to the treatment of organ dysfunction resulting from sepsis, including intensive care, invasive procedures, mechanical ventilation, dialysis and high cost of broad-spectrum antibiotics. The hospitalization for this period also reflects the high lethality of sepsis.

Regarding the classification of sepsis, in the current study we observed higher costs in patients diagnosed with severe sepsis compared to those with septic shock. The hypothesis for this result may be the severity of patients in shock. The majority of these patients progresses to death in short time, which would reduce the hospitalization period and, consequently, the costs with them. The same result was observed in a study conducted in France for a one-year period with the aim to document the costs and results for various forms of septic syndrome. The total average estimate for hospital costs were $€ 26,256, € 35,185$ and $€ 27,083$ for patients with sepsis, severe sepsis and septic shock, respectively ${ }^{(18)}$.

In a study conducted at the same institution that the present work, $46.5 \%$ of patients with infections related to health care have evolved with sepsis, increasing the risk of death by approximately six-fold ( $\mathrm{p}<0.001, \mathrm{RR} 5.87$ ), compared with patients who did not develop sepsis. The same study revealed septic shock was the most prevalent complication of sepsis (75\%), with a mortality rate reaching $81.3 \%$ of patients ${ }^{(19)}$.

Another negative scenario presented in a study showed that over half of the total value of sepsis treatment ( $\mathrm{R} \$ 2,215,773.50$; US\$ 989,626.00) was assigned to patients who progressed to death. This data is in agreement with international data, according to which over half of the full amount of money used in the treatment of septic patients $(57.0 \%)$ was used in patients who died ${ }^{(5,7)}$.

Still in Brazil, a multicenter observational cohort study was conducted in 2008 with septic patients hospitalized in 21 ICUs of public and private hospitals for a one-year period. Participants were followed since diagnosis of sepsis until the clinical outcome, and the direct costs of hospitalization were estimated. The results showed that the total average cost was US\$9,632.00 ( $\mathrm{R} \$ 21,566.00)$ per patient, 
and the average daily rate cost was significantly higher for non-survivors ${ }^{(11)}$.

The presented data warn the institutions about the need for investment in professional training for the early diagnosis and implementation of treatment at the appropriate time, in order to be more effective and contribute with patients' recovery, reducing the misdirection of investments that culminate in death ${ }^{(20)}$.

The creation of a team for research and control of sepsis using management protocols for early diagnosis and appropriate treatment has proven an effective strategy to improve health indicators, such as reducing the chances of evolving to death by $30 \%$, and reduction in days of hospital stay, which may reflect in reduction of hospital costs ${ }^{(20)}$.

Note the limitation of this study having been performed in a teaching hospital, where many factors influence costs in comparison to other health institutions. However, it is exactly in teaching hospitals where cases of severe sepsis treated in the Unified Health System are referred, such as for tertiary reference services, and where data of costs are organized and available. Another limitation was that costs were not calculated from detailed analysis of medical records, but from average costs of the units. Although this can result in lower accuracy, it also represents an estimate in real values calculated monthly.

The high costs involved in the treatment of severe sepsis and septic shock justify investments in prevention, early diagnosis and appropriate treatment of patients with sepsis. Training activities and the establishment of protocols that target preventive actions and optimize diagnosis and treatment in infected and septic patients can help to reduce mortality and improve the management of financial resources of health institutions.

\section{CONCLUSION}

The estimated hospitalization costs of patients with severe sepsis and septic shock are equivalent to $\mathrm{R} \$ 3,692,421.00$ (US\$1,649,138.40). The higher costs are related to discharge, diagnosis of severe sepsis, the pulmonary focus of infection and the age group of up to 59 years.

\section{RESUMO}

Objetivo: Estimar o custo da internação de pacientes com sepse grave ou choque séptico admitidos ou diagnosticados no setor de Urgências e Emergências de um hospital universitário e seguidos até o desfecho clínico. Método: Estudo epidemiológico, prospectivo e observacional, realizado em um hospital público do sul do Brasil, no período de 1 ano (agosto de 2013 a agosto de 2014). A coleta dos dados clínico-epidemiológicos utilizou fichas de notificação de sepse, prontuários e dados do setor de custos. Foi realizada análise de tendência central, dispersão e quartis dos custos das internações. Resultados: Amostra composta por 95 pacientes que totalizaram elevado custo da internação ( $\mathrm{R} \$ 3.692 .421,00)$, com média de $\mathrm{R} \$ 38.867,60$ por paciente. Mais da metade do valor total do tratamento da sepse $(\mathrm{R} \$ 2.215 .773,50)$ destinou-se a pacientes que evoluíram a óbito $(59,0 \%)$. Os maiores custos foram relacionados à alta, ao diagnóstico de sepse grave, ao foco infeccioso pulmonar e à faixa etária até os 59 anos. Conclusão: $\mathrm{O}$ elevado custo com o tratamento da sepse justificam investimentos em ações de capacitação e instituição de protocolos que possam direcionar ações preventivas, otimizar o diagnóstico e a terapêutica em pacientes infectados e séptico.

\section{DESCRITORES}

Sepse; Infecção Hospitalar; Custos e Análise de Custo; Custos Hospitalares.

\section{RESUMEN}

Objetivo: Estimar el costo de la estancia hospitalaria de pacientes con sepsis severa o choque séptico ingresados o diagnosticados en el sector de Urgencias y Emergencias de un hospital universitario y seguidos hasta el resultado clínico. Método: Estudio epidemiológico, prospectivo y observacional, realizado en un hospital público del sur de Brasil, en el período de 1 año (agosto de 2013 a agosto de 2014 ). La recolección de los datos clínico-epidemiológicos utilizó fichas de notificación de sepsis, fichas clínicas y datos del sector de costos. Se llevó a cabo análisis de tendencia central, dispersión y cuartiles de los costos de las hospitalizaciones. Resultados: Muestra compuesta de 95 pacientes que totalizaron elevado costo de la hospitalización ( $\mathrm{R} \$ 3.692 .421,00)$, con promedio de $\mathrm{R} \$ 38.867,60$ por paciente. Más de la mitad del valor total del tratamiento de la sepsis ( $\mathrm{R} \$ 2.215 .773,50)$ se destinó a pacientes que llegaron a fallecer $(59,0 \%)$. Los mayores costos estuvieron relacionados con el alta, el diagnóstico de sepsis severa, el foco infeccioso pulmonar y el rango de edad hasta los 59 años. Conclusión: El elevado costo con el tratamiento de la sepsis justifican inversiones en acciones de capacitación e institución de protocolos que puedan orientar acciones preventivas, optimizar el diagnóstico y la terapéutica en pacientes infectados y sépticos.

\section{DESCRIPTORES}

Sepsis; Infección Hospitalaria; Costos y Análisis de Costo; Costos de Hospital.

\section{REFERENCES}

1. Siqueira-Batista R, Gomes AP, Calixto-Lima L, Vitorino RR, Perez MCA, Mendonça EG, et al. Sepse: atualidades e perspectivas. Rev Bras Ter Intensiva [Internet]. 2011 [citado 2015 maio 2015];23(2):207-16. Disponível em: http://www.scielo.br/pdf/rbti/v23n2/a14v23n2.pdf

2. Siqueira-Batista R, Gomes APA, Santos V, Madalon-Fraga R, Aleksandrowicz AMC, Geller M. Ensino de imunologia na educação médica: lições de Akira Kurosawa. Rev Bras Educ Med. 2009;33(2):186-90.

3. Al Khalaf MS, Al Ehnidi FH, Al - Dorzi HM, Tamim HM, Abd-Aziz N, Tangiisuran B, et al. Determinants of functional status among survivors of severe sepsis and septic shock: one-year follow-up. Ann Thorac Med. 2015;10(2):132-6.

4. Silva E. Sepse, um problema do tamanho do Brasil [editorial]. Rev Bras Ter Intensiva [Internet]. 2006 [citado 2015 abr. 28];18(1):5-6. Disponível em: http://www.scielo.br/pdf/rbti/v18n1/a01v18n1.pdf 
5. Instituto Latino Americano de Sepse. Campanha Sobrevivendo a Sepse. Relatório Nacional, 2014. [Internet]. São Paulo; 2014 [citado 2015 abr. 28]. Disponível em: http://www.ilas.org.br/upfiles/fckeditor/file/Relat\%C3\%B3rio\%20Nacional\%20fev\%202014.pdf

6. Hospital Sírio Libanês, Comitê Executivo do Protocolo. Diagnóstico e Tratamento Precoce da Sepse Grave no Adulto [Internet]. São Paulo; 2014 [citado 2015 abr. 25]. Disponível em: https://www.hospitalsiriolibanes.org.br/institucional/gestao-da-qualidade/Documents/ protocolo-sepse-0314.pdf

7. Angus DC, Linde-Zwirble WT, Lidicker J, Clermont G, Carcillo J, Pinsky MR. Epidemiology of severe sepsis in the United States: analysis of incidence, outcome, and associated costs of care. Crit Care Med. 2001;29(7):1303-10.

8. Koenig A, Picon PD, Feijó J, Silva E, Westphal GA. Estimativa do impacto econômico da implantação de um protocolo hospitalar para detecção e tratamento precoce de sepse grave em hospitais púbicos e privados do Sul do Brasil. Rev Bras Ter Intensiva [Internet]. 2010 [citado 2015 abr. 28];22(3):213-9. Disponível em: http://www.scielo.br/pdf/rbti/v22n3/01.pdf

9. Levy MM, Fink MP, Marshall JC, Abraham E, Angus D, Cook D, et al. SCCM/ESICM/ACCP/ATS/SIS International Sepsis Definitions Conference, 2001. Crit Care Med. 2003;31(4):1250-6.

10. Horan TC, Andrus M, Dudeck M. CDC/NHSN surveillance definition of health care-associated infection and criteria for specific types of infections in the acute care setting. Am J Infect Contr. 2008;36(5):309-32.

11. Sogayar AM, Machado FR, Rea-Neto A, Dornas A, Grion CM, Lobo SM, et al. Costs Study Group - Latin American Sepsis Institute. A multicentre, prospective study to evaluate costs of septic patients in Brazilian intensive care units. Pharmacoeconomics. 2008;26(5):425-34.

12. Lahiff C, Cournane S, Creagh D, Fitzgerald B, Conway R, Byrne D, et al. Factors predicting the hospital episode costs of emergency medical admissions. Eur J Int Med. 2014;25(7):633-8.

13. Adrie C, Alberti C, Chaix-Couturier C, Azoulay É, Lassence A, Cohen Y, et al. Epidemiology and economic evaluation of severe sepsis in France: age, severity, infection site, and place of acquisition (community, hospital, or intensive care unit) as determinants of workload and cost. J Crit Care. 2005;20(1):46-58.

14. Greco G, Wei S, Michler RE, Meltzer DO, Ailawadi G, Hohmann SF, et al. Costs Associated With Health Care-Associated Infections in Cardiac Surgery. J Am Coll Card [Internet]. 2015 [cited 2015 Apr. 28];65(1):15-23. Available from: http://www.ncbi.nlm.nih.gov/pmc/ articles/PMC4293042/

15. Couto DO, Peixoto Júnior AAP, Farias JLM, Sales DB, Lima JPA, Rodrigues RS, et al. Associação entre sexo e mortalidade em pacientes com sepse: os hormônios sexuais influenciam o desfecho? Rev Bras Ter Intensiva [Internet]. 2011 [citado 2015 abr. 28];23(3):297-303. Disponível em: http://www.scielo.br/pdf/rbti/v23n3/v23n3a07.pdf

16. Calderon C, Rodolfo D. Costos económicos de neumonía adquirida en comunidad, meningitis y bacteriemia por Streptococcus pneumoniae en una población adulta que requirió hospitalización en Bogotá, Colombia. Biomédica [Internet]. 2014 [citado 2015 Abr. 28];34:92-101. Disponible en: http://www.revistabiomedica.org/index.php/biomedica/article/view/1553

17. Alberti C, Brun-Buisson C, Burchardi H, Martin C, Goodman S, Artigas A, et al. Epidemiology of sepsis and infection in ICU patients from an international multicentre cohort study. Int Care Med. 2002;28(2):108-21.

18. Brun-Buisson C, Roudot-Thoraval F, Girou E, Grenier-Sennelier C, Durand-Zaleski I. The costs of septic syndromes in the intensive care unit and influence of hospital-acquired sepsis. Int Care Med. 2003;29(9):1464-71.

19. Souza ES, Belei RA, Carrilho CMDM, Matsuo T, Yamada-Ogatta SF, Andrade G, et al. Mortality and risks related to healthcare-associated infection. Texto Contexto enferm. [Internet]. 2015 [cited 2015 May 05];24(1):220-8. Available from: http://www.scielo.br/pdf/tce/ v24n1/0104-0707-tce-24-01-00220.pdf

20. Umscheid CA, Betesh J, Van Zandbergen C, Hanish A, Tait G, Mikkelsen ME, et al. Development, implementation, and impact of an automated early warning and response system for sepsis. J Hosp Med [Internet]. 2015 [cited 2015 Abr 28]; 10(1):26-31. Available from: http://www.ncbi.nlm.nih.gov/pmc/articles/PMC4410778/ 